\title{
INTELLIGENCE FUNCTION OF OPERATIVELY-SEARCH ACTIVITIES OF THE UKRAINIAN NATIONAL POLICE: QUESTIONS OF CONCEPTUALIZATION AND PROCDUALIZATION
}

\section{Albul S. V.}

\section{INTRODUCTION}

Political and social processes which taking place in Ukraine, accelerated criminalization of the society, which can be seen, first of all, in changes of quantitative and qualitative characteristics of crimes, consolidation of criminal underground and expanding of its sphere of influence on society, destruction or deformation of basic governmental and social institutions, marginalization of the citizens, formation of legislative skepticism and mass anomia and loss of social values as a consequence. At the same time, European choice of Ukraine calling for creation and implementation of innovative approach to theory and practice of the law enforcement and legislative practices. Contemporary organized crimes influencing many global social-economic processes like urbanization, international and regional migrations, formation of the worldwide informational-cultural space, and one of the characteristics of organized criminal organizations is relatively high level of organization, strong corruptive and international criminal connections ${ }^{1}$.

Ever increasing level of organization and professionalism of crimes, their technical capabilities, creation and strengthening of immunity of criminal elements to traditional methods and practices of operativelysearch activities, well developed corruption connections, promotes conversion of criminal groups into highly organized entities, with welldeveloped infrastructure. From this viewpoint raises necessity for studying international practices of police activities related to counteractivities to various crimes and especially to organized ones.

1 Дрёмин В. Н. Преступность как социальная практика: институциональная теория криминализации общества : монография. Одесса : Юридична література. 2009. C. 37. 
Creation of contemporary counteractivities to organized crimes calling for new approaches to developing, analytical processing and usage of operatively-search information, which was procured by many means including those of operative and operatively-technological with the goal of timely prevention, detection and neutralization of real and potential threats to national interests of Ukraine $^{2}$. All divisions of National police will be required to actively use, inside the guidelines of current law, clandestine methods of operatively-search activities and specific means of obtaining operating information, documented facts of unlawful activities etc., one of which represents realization of intelligence function of operatively-search activities of the National police.

Particular problems of organization and tactical realization of intelligence function of operatively-search activities was highlighted in articles of the following scientists: I.G. Basetsky, A.S. Vandishev, M.P. Vod'ko, A.F. Volinsky, D.V. Grebelsky, I.G. Grichanin, L.M. Kalinkovich, V.A. Lukashov, S.S. Ovchinsky, V.G. Samoilov, V.A. Samohin, V.V. Sergeyev and others. Following scientists was studying psychological aspects of these activities: B.E. Baranenko, V.A. Cherepanov, U.V. Chufarovskij and others. In their research, contemporary scientists like: M.I. Anufriev, O.M. Bandurka, G.M. Birukov, O.U. Busol, M.L. Gribov, E.O. Didorenko, O.F. Dolzhenkov, V.P. Zaharov, I.P. Kozachenko, Y.U. Kondratiev, O.E. Koristin, V.A. Nekrasov, D.J. Nikiforchuk, M.M. Perepelisa, S.I. Pichkurenko, M.A. Pogoretsky, E.V. Ryzhkov, M.B. Saakjan, I.V. Servetskiy, V.E. Tarasenko, V.V. Shendrik, I.R. Shinkaretko and others, studied only some aspects of organization and tactics of realization of intelligence function of operatively-search activities of the National police. Furthermore, we must point out the fact, that comprehensive monographic studies of common-theoretical, legislative and organizationally-tactical principles of realization of intelligence function of operatively-search activities of the National police of Ukraine was not conducted until now. Realization of the situation today happens under conditions of forming of the new paradigm of operatively-search

${ }^{2}$ Albul S. V. Criminal Intelligence as a Function of Operatively-Search Activity: European Experience and Ukrainian Prospects). European Reforms Bulletin: international scientific peer-reviewed journal. Grand Duchy of Luxembourg, 2015. № 2. P. 4. 
activities, and many issues will require fundamentally new scientific research, especially in the area of conceptualization and establishing procedures for such activities.

\section{Essence of Intelligence Function of Operatively-Search Activities of the National Police of Ukraine}

As of today, there is no unified vision for recognizing intelligence function of operatively-search activities of the National police. Scientific foundation for clearly defining directions and ways to recognize intelligence function of operatively-search activities of the National police are also absent. There are no studies of intelligence function of operatively-search activities of the National police from the viewpoint of specific activities, synergetic and epistemological approaches, and their information-predictive essence.

As of today this function of operatively-search activities quite clearly defined in legislative norms at different levels and numerous branches, such as Criminal and Criminal-procedural codes of Ukraine, Ukrainian laws «About National police», «About operatively-search activities», «About organizationally-legislative basis of fighting organized crime», a series of departmental and inter-departmental normative acts, and in particular joint act of the office of Prosecutor's General of Ukraine, MIA of Ukraine, SS of Ukraine, Ukrainian Ministry of finance, Ukrainian border protection Administration, Ministry of Justice from 16.11.2012 № 114/1042/516/1199/936/1687/5 «About organization and execution of investigative (search) actions and using results in criminal proceedings» etc. Current Ukrainian law «About operatively-search activities», which acts as basis for forming directions for operatively-search activities, suggests that «operatively-search activities is a system of open and secret search, intelligence and counterintelligence means which performed by means of operative and operatively-technological activities $)^{3}$. This law establishes comprehensive list of state's bodies, which have rights to perform operatively-search activities. At first glance, logic-semantics analysis of the norms of above mentioned Law, gives us an opportunity to confirm

3 Про оперативно-розшукову діяльність : Закон України від 18.02.1992 p. № 2135-XII. Дата оновлення: 17.04.2019. URL: http://zakon1.rada.gov.ua (дата звернення 20.04.2019). 
that defined subjects, besides National police, have rights to perform operatively-search activities. We are convinced that intelligence is one of the functions of operatively-search activities. Operative divisions of National police realizing intelligence functions by means of the system of intelligence, search, informational-analytical methods, including those from collection of operative and operatively-technological activities with the goal of timely prevention, discovery and neutralization of real and potential threats to national interests of Ukraine from crimes ${ }^{4}$.

In article 8 of Law of Ukraine «About operatively-search activities» stated that certain subjects have rights to infiltrate into criminal organization as secret workers of the operative subdivision, or subject, who is cooperating with the latter, and keeping real information about their personality secret, create fake enterprises and organizations, produce documents which conceal a person or relationship of a persons, premises and means of transportation of operative subdivisions. Furthermore, article 13 of Law of Ukraine «About organizationallegislative foundation of combating organized crime» stated that while fighting organized crime, operative subdivisions have rights to employ secret cooperators, which can be introduced into criminal groups undercovered, providing that there was no other means for uncovering organized crimes and bringing these criminals to justice ${ }^{5}$.

At the same time, article 9 of Law of Ukraine «About intelligence organs of Ukraine» suggests, that subjects of intelligence activities have rights to use documents which conceal employees and organizational affiliation of subdivisions, organizations, premises and means of transportation with intelligence organs of Ukraine; for conspiracy reasons create organizational structures, which are required in order to fulfill requests from intelligence organs of Ukraine and to cover their workers, and use money and property acquired as a result of their activities, in accordance with the guidelines of the Cabinet of Ministers of Ukraine ${ }^{6}$.

4 Копан О. В. Забезпечення внутрішньої безпеки України: теоретикоуправлінські заходи. Введення в поліцейську стратегію : монографія. Київ : НАВС, 2001. C. 27.

5 Про організаційно-правові основи боротьби 3 організованою злочинністю : Закон України від 30.06.1993 р. № 3341-XII. Дата оновлення: 15.04.2019. URL: http://zakon1.rada.gov.ua (дата звернення 20.04.2019).

${ }^{6}$ Про розвідувальні органи України : Закон України від 22.03.2001 р. № 2331. Дата оновлення: 18.04.2019. URL: http://zakon1.rada.gov.ua (дата звернення 19.04.2019). 
Current Criminal Procedural codex of Ukraine categorizes execution of the special task of uncovering unlawful activities by organized group or organization as a clandestine investigative (search) activities. According to article 272 of CPC of Ukraine, it is possible, in time of pre-trial investigation of serious or especially serious crimes, to obtain information, things and documents, which are important for pretrial investigation, by a person, who, according to law, is performing a special task by infiltrating into criminal group or organization, or is a member of such group or organization, who are confidentially cooperating with the organs of pre-trial investigation ${ }^{7}$. At the same time, join order General Prosecutor of Ukraine, MIA of Ukraine, SS of Ukraine, Ukrainian Ministry of finance, Ukrainian border protection Administration, Ministry of Justice from 16.11.2012 № 114/1042/516/1199/936/1687/5 «About organization and execution of investigative (search) actions and using results in criminal proceedings» suggests, that performing of special task for uncovering unlawful activities of organized group or criminal organization is in organizing of investigative and operative subdivision and in introduction by them of an authorized person, who, according to law, will be performing such special task while working undiscovered in organized group or criminal organization and is procuring things and documents, which are important evidences in investigation of a crime or crimes committed by these groups ${ }^{8}$. Analysis of provisions of current laws, in our opinion, demonstrating that existing situation of the law provisioning of realization of intelligence functions of operativelysearch activities is seemingly complete, at the first glance, but with more detailed review reveals the need for improvement by taking under consideration intersectional connections, correlation of terms and definitions, specialization in organization and tactics of entire law enforcement activities.

${ }^{7}$ Кримінальний процесуальний кодекс України : Закон України від 13.04.2012 p. № 4651-VI. Дата оновлення: 19.04.2019. URL: https://zakon.rada.gov.ua/laws/ show/4651-17 (дата звернення 20.04.2019).

8 Про організацію проведення негласних слідчих (розшукових) дій та використання їх результатів у кримінальному провадженні : наказ Генеральної Прокуратури України, МВС України, СБ України, Міністерства фінансів України, Адміністрації Державної прикордонної служби України, Міністерства юстиції України від 16.11.2012 № 114/1042/516/1199/936/1687/5. Дата оновлення: 17.04.2019. URL: https://zakon.rada.gov.ua/laws/show/v0114900-12 (дата звернення 19.04.2019). 
According to current law the goals of operatively-search activities is procuring and fixation of the facts related to unlawful acts of subjects and groups, responsibilities for counter intelligence and destabilization activities by special services of the foreign countries and organizations based on the guidelines of the Criminal Code of Ukraine and with the goal to stop crime and in the interest of criminal legal proceedings, as well as for the purposes of obtaining information in the interest of safety of citizens, society and the state ${ }^{9}$. At the same time, while performing such duties, they are realizing all functions of operatively-search activities. But when we are talking about intelligence function, it worth pointing out that while performing these activities, tasks can be enhanced by: obtaining, analytical processing and sharing information with authorized bodies of state power with the goal of using such information in legislative, law enforcement and executive activities of the country; counteraction to organized criminal groups, infiltration of their members into government organizations, and expanding their influence on processes which take place in the country and society; prevention of real threats to national interests from organized crime, prevention of events and factors which can respond to such factors and create potential threat to national interests and national security of Ukraine; development and implementation of methods for neutralization and liquidation of organized criminal groups, creation of conditions for their uncovering by other means, participation in combatting international criminal activities.

Detailed knowledge of strategic situation, possible ways of their development, predicting emergence of dangerous situations creating preconditions for determining national interests; development of required policies for internal security; improving level of details of tasks for law enforcement; development of general strategy and necessary plan of actions. Successful implementation of those decisions if fully dependent on quality of information received, which can be provided by proper implementation of intelligence function of operatively-search activities. As it was rightfully outlined by the scientists, operatively-search activities in by itself is nothing more, but a cyclical process of searching for,

9 Оперативно-розшукова діяльність органів внутрішніх справ : Загальна частина : підручник / С. В. Албул, К. І. Бєляков та ін. ; за ред. С. П. Черних, М. П. Водька, О. Ф. Долженкова. Київ : Відділ редакційно-видавничої діяльності МВС України, 2012. 884 с. 
collecting, processing and timely use of operatively-search and other types of information ${ }^{10}$. The very objects which are the targets of implementation of operatively-search activities of National police are the criminal environment and its infrastructure ${ }^{11}$. As of today, the meaning of «criminal environment» covers not only crimes that already happened, but criminal ideology, criminal society and individual psychology, and other factors which collectively describe criminal activities. Some specialists using words «intrusive criminality» in their research, which, first of all, means that it penetrates, building on and plays an important role in the system of legislative, financial, and other relationships, gradually changing political, cultural and spiritual life of the society ${ }^{12}$. As for criminal environment, in our opinion, intrusiveness can be seen in two aspects: first, determination of the crime, which in turn acts as an element of the criminal environment; and second, as a functional determinant of the criminal environment itself, which gives it an ability to expand into spheres of a social life. This description becomes especially important under conditions of deep social crisis, when social system can no longer develop under circumstances of exhausted resources and sense of existence. At this time, when old system of the society is losing its abilities, the crisis of development is growing with stagnation at the background, and in the absence of the resource for renewal.

There are number of definitions of word «intelligence» in scientific and reference literature. For example, some thesaurus contains following definition: «intelligence is an act of collecting information about the enemy, at the peace times utilizing agents, spies, maps, plans, statistical data etc.; and during the war - using deserters and prisoners». According to specialists, from the philology standpoint, basis of the word «intelligence» derived from «obtaining information», or presence of the knowledge regarding some object. Amongst many definitions of «intelligence» most broad one is: special knowledge; type of

${ }^{10}$ Galuychek A. The Use of Undercover Forces in Law Enforcement Agencies of the Ukraine in Organized Crime Fighting: The Legal Aspect. Law Enforcement Executive Forum. USA, Illinois, 2005. № 5 (4). P. 59.

11 Albul S. V. Philosophic Concepts of the Intelligence Function within the Operative-Investigative Activity of the National Police of Ukraine. European Reforms Bulletin: international scientific peer-reviewed journal. Grand Duchy of Luxembourg, 2017. № 1. P. 8.

${ }^{12}$ Gribov M. L. The improvement of the institute of secret investigatory operations. EuroAmerican Scientific Cooperation. Ontario, Canada, 2014. № 2. P. 77. 
organization; process of obtaining knowledge. Sound definition of «intelligence», in our opinion, given by M. P. Vod'ko - «intelligence is an activity of authorized subjects who, by employing special means and methods, obtain information about ideas, plans and means by which the enemy can potentially or actually cause harm to objects of protection» ${ }^{13}$.

Intelligence process starts with learning, analysis and assessment of operation situation, which currently exists. Operation situation, which is forming on a territory, object, direction of operation's service in the city, district, area, region and in the country in general is a complex of interconnected situations and processes, organized objective cause-consequence dependencies and natural way of development. When such studies and analysis produce results, they can be used for setting goals (tactical and strategic). And only after goals are set, we can start planning process.

Planning is a process of decision making, which helps to reach set goals, it is making decision in advance as to who, when and how is performing tasks; it is a process of making decisions about the future as to what, by whom and when thing should be done. As for intelligence, at the time of planning shall be determined forces and means, which are required for procuring of operatively important information. Collection of such information is performed by the employees of operating subdivisions of National police. It is possible to request additional information by means of concretization or by assigning additional tasks during the time of procurement of initial operatively important information, and by making decisions about use of additional forces and means ${ }^{14}$. Obtained operatively important information should be analyzed, acted on and is transformed into new, previously unknown operatively-search information, which should be properly documented ${ }^{15}$. Only after properly documenting, the results can be issued to authorized leaders for review, making appropriate decisions and making prognoses regarding possible developments of the situation of forming of the new tendencies. By obtaining operatively-search information, better general

${ }^{13}$ Водько Н. П. Формирование политики противодействия уголовным правонарушениям в Украине (оперативно-розыскной аспект) : монография. Одесса : Феникс, 2015. С. 118.

${ }_{15}^{14}$ Hirschmann Kai. Geheimdienste. Hamburg : Sabine Groenewold Verlag, 2004. 52 s.

${ }^{15}$ Цехан Д. М. Інформація як змістовна складова ОРД. Південноукраӥнський правничий часопис. Одеса, 2009. № 2. С. 68. 
operating picture is formed, hence new tactical and strategic goals can be set and new directions, forces and means can be dedicated for achieving these goals. This represents the meaning of the cyclicality of the process of realization of function of operatively-search activities. Therefore, intelligence cycle can be defined as goals oriented, planned process, which allows assigned subjects who conduct investigation, to analyze and estimate state of operative situation, collect operatively important data (information), concentrate and transform it into operative-search information and provide it to authorized leaders for decision making and forming prognoses.

\section{Directions of Conceptualization and Processualization of Intelligence Function of Operative-Search Activities of National Police of Ukraine}

Contemporary criminal situation in Ukraine is qualitatively new phenomenon based on the scale of criminal activities, as well as the level of their negative influence on livelihood of society, law and individual freedoms of the citizens ${ }^{16}$. In the last couple of years organized crime in our country has been transformed, increased number of criminal groups, who have well defined hierarchical structure, utilizing new technological means of performing unlawful activities, counter-acting law enforcement agencies. Today, dynamics and structure of crime, together with traditional conditions and circumstances, carrying above mentioned criminal factors, which arises from social difficulties and economic development of the society. At this background happened shift in measuring social values by certain groups of citizens toward unlawful way of living, which in turn leads to strengthening of such a socially dangerous phenomenon as organized crime ${ }^{17}$.

Existing system of providing for internal security in Ukraine in general was adequate for conditions under which country existed in the first years of independence. However, the situation around national security, which formed at the beginning of the XXI st. century, because

16 Дрёмин В. Н. Преступность как социальная практика: институциональная теория криминализации общества : монография. Одесса : Юридична література. 2009. С. 58.

${ }^{17}$ Водько Н. П. Формирование политики противодействия уголовным правонарушениям в Украине (оперативно-розыскной аспект) : монография. Одесса : Феникс, 2015. С. 114-115. 
of widening of the spectrum of demands and perils, demanding new approaches to the system of providing internal security in Ukraine, and is overdue for modifications ${ }^{18}$. Very loosening of the state control over situation in the country gives opportunity for criminal elements set tone and dictate their own rules of behavior, ideology, subculture, cherish useful for their existence legislative, organizational and tactical decisions of the government, promote active opposition to law enforcement. To organize unlawful activities they are operating large financial resources, which, in particular, are used to bribe state officials, employees of law enforcement structures, financing specialists in various fields to create an effective mechanisms, technologies, approaches and schemes for committing crimes.

We convinced that effective counteractions to crime and especially in their organized forms, is impossible without understanding of processes which taking place in criminal environment or in turn creating of required conditions for documenting facts of unlawful activities. In connection with this, National police is facing the need to understand conditions leading to creation and existence of criminal formations, mechanisms by which they are causing harm, roles of each participant of criminal group in this process, movement of the shadow and legal financial instruments, which provides basis for these groups or represent target of their criminal interests, functioning of the infrastructure of organized crime etc.

Comparative analysis contemporary European and world practice showing that most developed countries taking the path of clear separation between criminal-procedural activities and actions related to procuring, development, analytical processing and prognostication of information about crime, separate crimes and persons related to them ${ }^{19}$. Exactly these activities can be called as criminal intelligence.

Most developed network of intelligence subdivisions exists in USA police, where every subdivision has its own intelligence group, which, depending on the level, can contain information-analytical subdivision, operatives, special operations group, experts, operative group, which

${ }^{18}$ Копан О. В. Забезпечення внутрішньої безпеки України: теоретико-управлінські заходи. Введення в поліцейську стратегію : монографія. Київ : НАВС, 2001. 423 c.

${ }^{19}$ Бандурка О. М., Перепелиця М. М., Манжай О. В., Шендрик В. В. Оперативно-розшукова компаративістика : монографія. Харків : Золота міля, 2013. С. 73. 
works «under cover», external and electronic surveillance and materialtechnical support group ${ }^{20}$. General reason for existence of intelligence service of USA police is collection of operating information, which can provide for effective planning and realization of anti-criminal activities. This type of intelligence is called «internal intelligence» ${ }^{21}$.

Similar subdivisions exist in French police-search and capture brigades. They utilize active measures for studding criminal elements and tracking them by infiltrating into their environment. The same approach is used by organization of special subdivisions in Switzerland. Rich experience utilizing intelligence subdivisions in crime-combatting activities is in the arsenal of Hungarian police. In its disposal there are groups of well undercover workers, specially trained for work inside of criminal environment. At the same time, criminal police in Germany and department for constitutional protection similarly using undercover operatives, primarily for uncovering severe and capital crimes ${ }^{22}$. Interestingly that in year 2012 Lithuanian republic adopted the Law «About criminal intelligence», which replaced the Law «About operatively-search activities». With adoption and implementation of new the law crime counter-action activities in Lithuanian republic consists of two, logical parts: intelligence activity and criminal-procedural one.

We must point out that with adoption of Criminal procedural code of Ukraine in 2012, operative-search activities had lost their offensive character. Operative sub departments in guardrails of criminal processing stripped out of the rights to energetically provide activities related to detection and documenting criminal activities. In fact, operative-search activities end after investigative subdivisions starts their criminal investigation. This situation leads to loss of operative positions and preventative nature of activities of National police. We convinced, that under this circumstances, establishing of criminal

${ }^{20}$ Савченко А. В., Матвійчук В. В., Никифорчук Д. Й. Міжнародний досвід використання агентури правоохоронними органами держав Європи та США : посібник / А. В. Савченко, В. В. Матвійчук, Д.Й. Никифорчук / За ред. Я. Ю. Кондратьєва. Київ : НАВС, 2004. С. 68.

${ }^{21}$ Шендрик В. В. Міжнародний досвід використання підрозділів поліції для отримання оперативно-розшукової інформації. Право $i$ Безпека. Київ, 2009. № 1. C. 24 .

${ }^{22}$ Еенбум Е. Ш. Розвідки Північної Америки, Свропи та Японії. Країнознавчий портрет і аналіз : монографія. Вайнгайм : Вид-во. Stoppel, 1995. С. 84-85. 
intelligence as integral part of operative-search activities of National police, can bring positive results in counter-acting contemporary crime and requires conceptualization. We are certain, that criminal intelligence is one of the functions of operative-search activities of National police and should be realized by implementation of system, consisting of intelligence, search, information-analytical methods, including utilization of operative and operative-technical means, directed to timely prevention, detection and neutralization of real and potential criminal threats to national interests of Ukraine. Ways of creation of criminal intelligence are organizationally-tactical forms operative search, operatively-search prevention and operative development. Besides these, criminal intelligence activities must continue during pre-trial investigation and in time of execution of the punishment $^{23}$.

We are convinced that following problems which are getting solved by criminal intelligence of National police are: obtaining, analytical processing and providing of information regarding situation and possible developments of criminal activities in the country and its consumption in country's activities; assistance in implementation political activities of Ukraine for crime prevention; suppression of activities of organized criminal groups, infiltration of their members into state governments and expansion of their influences on processes in the country and society; prevention of realization of threats to national interests from organized crime; development and realization of the methods for neutralization and liquidation of organized criminal groups, creation of adequate conditions for discovering such groups; participation in international fighting efforts against organized crime.

Thinking about directions for conceptualization of intelligence function of operative-search activities of National police, we must point out that following problems must be solved as soon as possible:

1) Improving laws in the sphere of operative-search counteractions to crimes;

2) Conceptual designation of criminal intelligence of National police and its methodological foundation;

${ }^{23}$ Albul S. V. Criminal Intelligence as a Function of Operatively-Search Activity: European Experience and Ukrainian Prospects). European Reforms Bulletin: international scientific peer-reviewed journal. Grand Duchy of Luxembourg, 2015. № 2. P. 5. 
3) Establishment of studying of the latest information regarding intelligence activities of police and law enforcement agencies of foreign countries;

4) Legislative and normative provisioning of activities of National polis of Ukraine as for counteracting crime;

5) Introduction and constant monitoring of national system of prevention and crime counteraction based on modeling of its strength to different kinds of criminal endangerment to person, society and country;

6) Continuation of the process of adaptation of the national laws to those from the European Union in the areas of crime prevention and counteractions;

7) Initiation of improvements of international legislative acts and harmonization of national law in the areas of crime counteraction with similar laws of the European Union;

8) Rebuilding organization structure of operative subdivisions on National police of Ukraine to counteract crime, structural optimization and staff numbers in subdivisions by taking into consideration real criminal treats to safety of people, society and country, as well as based on providing vertical system of managing corresponding subdivisions and regional branches;

9) Raising level of cooperation between National police and other state agencies for providing better crime prevention and counteraction;

10)Improving existing and development of new methods for counteracting crimes;

11)Improving information-analytical provisioning based on innovative approaches to utilization of contemporary informational and telecommunications technologies and conversion of informationreferential work into intelligence-analytical with the goal to create prognosis of tendencies of society criminalization, quantifying degrees of risk and the scale on reginal, national and international levels as well as lowering latency levels of crimes;

12)Performing constant system analysis and multidimensional complex evaluation of reasons and conditions, which determine crime and risks of its expansion;

13) Strengthening, increase of efficiency and maximum realization of opportunities for international cooperation for crime prevention, including organized forms of the crime; 
14)Establishing constant experience exchange with law enforcement from other countries, internship and training of corresponding specialists abroad;

15)Implementation of results of scientific research in the sphere of crime prevention, especially in operative-search activities;

16) Carrying out scientific researches to analyze the effectiveness of legislation and measures taken by state authorities in the field of prevention and counteraction to crime, information, organizational, scientific and methodological provision of this area of law-enforcement activity;

17)Improvement, in accordance with current needs and international experience, of the level of professional training of employees engaged in operational search activities;

18)Complex solution of issues of providing qualified personnel potential, based on professionalism, professionalism, personal moral qualities, etc.;

19) Proper resource and logistical support of units that carry out criminal intelligence;

20) Raising awareness of the society about the danger and scale of crime;

21)Formation of public opinion in order to facilitate the effective implementation of state policy in the field of prevention and counteraction of crime ${ }^{24}$.

An important prerequisite for the conceptualization and processualisation of operative-search activities of the National Police is the development of a fundamentally new legal framework that would allow qualitative performance of tasks in this area. According to art. 272 of the Criminal Procedural Code of Ukraine, in the course of pre-trial investigation of grave or especially grave crimes, information, things and documents that are relevant for a pre-trial investigation, a person who, in accordance with the law, performs a special task, participating in an organized group or a criminal organization, may receive information, or is a member of the group or criminal organization that cooperates with the pre-trial investigation authorities on a confidential basis. The

${ }^{24}$ Albul S. V. Criminal Intelligence as a Function of Operatively-Search Activity: European Experience and Ukrainian Prospects). European Reforms Bulletin: international scientific peer-reviewed journal. Grand Duchy of Luxembourg, 2015. № 2. P. 6. 
fulfillment of a special task cannot exceed six months, and if necessary, the term of its execution shall be extended by the investigator for a term not exceeding the term of pre-trial investigation ${ }^{25}$. In practice, this is a complex special operational-search operation, which is carried out directly by secret employees. Only the organization and preparation of such an operation takes time that can significantly exceed the six-month period, since its implementation involves a significant potential of a large number of specialists.

In accordance with Part 6 of art. 246 of the Criminal Procedural Code of Ukraine to conduct secret investigations (investigations) has the right of an investigator who conducts pre-trial investigation of a crime, or on his behalf - authorized operational units. The analysis of the above norms, as well as the practice of their application, gives grounds for arguing that the special task of disclosing the criminal activity of an organized group is directly carried out by the unscrupulous employees of the operational units introduced into the criminal environment. An investigator who conducts a pre-trial investigation of a crime, the prosecutor does not perform such a special task, and decide on its execution. In turn, the authorized operational units on behalf of the investigator carry out the organization of its conduct.

In order to align with the provisions of the theory and practice of operatively-search activities, it is necessary to make changes in art. 272 of the Criminal Procedure Code of Ukraine and in clause 8 of art. 8 of the Law of Ukraine " About operatively-search activities», namely: The title of article 272 of the Criminal Procedural Code of Ukraine should be worded as follows: «The introduction of an undercovered officer of an operational unit into an organized group or criminal organization»».

Part 2 of article 272 of the Code of Criminal Procedure of Ukraine should be worded as follows: «The introduction of secret employees into an organized group or a criminal organization for the purpose of performing a special task is carried out on the basis of a resolution of the investigator agreed with the head of the pre-trial investigation body or a resolution of the prosecutor with the preservation of confidential information about the person».

25 Кримінальний процесуальний кодекс України : Закон України від 13.04.2012 p. № 4651-VI. Дата оновлення: 19.04.2019. URL: https://zakon.rada.gov.ua/ laws/show/4651-17 (дата звернення 20.04.2019). 
Paragraph 8 of article 8 of the Law of Ukraine «About operativelysearch activities» «The Rights of Departments Investigating Operational Investigations» shall be worded as follows: to introduce secret employees into an organized group or a criminal organization and perform a special task on the disclosure of organized activities of a criminal group or a criminal organization according to the provisions of art. 272 of the Code of Criminal Procedure of Ukraine.

In our opinion, the introduction of appropriate amendments and additions to the Criminal Procedural Code of Ukraine and the Law of Ukraine «About operatively-search activities» will contribute to unification of the national legislation of Ukraine to international norms in the field of combating crime.

\section{CONCLUSIONS}

Conceptualization and processualization of the intelligence function of the operational and investigative activities of the National Police of Ukraine is seen in the following areas:

1. Scientific substantiation of the conceptualization and proceduralization of the intelligence function of the operational police of the National Police.

2. Legislative support for the conceptualization and processualization of the intelligence function of the operative and investigative activities of the National Police, namely: the drafting of the Law "About Criminal Intelligence"; the introduction of amendments and additions to the Criminal Code, the Criminal Procedural Codes, the Laws «About National police», «About operatively-search activities», «About Organizational-Legislative Foundations of Combating Organized Crime», «About Intelligence Authorities of Ukraine», as well as to departmental normative acts.

In our view, the conceptualization and processualization of the intelligence function of the operatively-search activities of the National police of Ukraine will dramatically increase the fight against crime, increase the effectiveness of timely detection and overcoming the threats of criminalization of society.

\section{SUMMARY}

In this article author introduces the definition and general characteristics of criminal intelligence as a separate function of 
operatively-search activities of the Ukrainian National police. Author substantiating his point of view for most problematic questions based on analysis of scientific literature, acting law and international practice of law enforcement activities, and is proposing concrete modifications in order to improve current laws. He is analyzing contemporary police practices of the USA and countries of the European Union related to existing police intelligence practices. Author explaining directions for conceptualization and establishing concrete procedures of the intelligence function of operatively-search activities of the Ukrainian National police. He clearly demonstrating the need to create Concept for development of the criminal intelligence of National police. He outlines the tasks, goals and major approaches for realization of such Concept. Furthermore, he proposes modernization of the legislative foundation of activities of the National police, Criminal Procedures Code and the Law «About operatively-search activities».

\section{REFERENCES}

1. Дрёмин В. Н. Преступность как социальная практика: институциональная теория криминализации общества : монография. Одесса : Юридична література. 2009. 613 с.

2. Albul S. V. Criminal Intelligence as a Function of OperativelySearch Activity: European Experience and Ukrainian Prospects). European Reforms Bulletin: international scientific peer-reviewed journal. Grand Duchy of Luxembourg, 2015. № 2. P. 2-6.

3. Про оперативно-розшукову діяльність : Закон України від 18.02.1992 p. № 2135-XII. Дата оновлення: 17.04.2019. URL: http://zakon1.rada.gov.ua (дата звернення 20.04.2019).

4. Копан О. В. Забезпечення внутрішньої безпеки України: теоретико-управлінські заходи. Введення в поліцейську стратегію : монографія. Київ : НАВС, 2001. 423 с.

5. Про організаційно-правові основи боротьби з організованою злочинністю : Закон України від 30.06 .1993 р. № 3341-XII. Дата оновлення: 15.04.2019. URL: http://zakon1.rada.gov.ua (дата звернення 20.04.2019).

6. Про розвідувальні органи України: Закон України від 22.03.2001 p. № 2331. Дата оновлення: 18.04.2019. URL: http://zakon1.rada.gov.ua (дата звернення 19.04.2019). 
7. Кримінальний процесуальний кодекс України : Закон України від 13.04.2012 р. № 4651-VI. Дата оновлення: 19.04.2019. URL: https://zakon.rada.gov.ua/laws/show/4651-17 (дата звернення 20.04.2019).

8. Про організацію проведення негласних слідчих (розшукових) дій та використання їх результатів у кримінальному провадженні : наказ Генеральної Прокуратури України, МВС України, СБ України, Міністерства фінансів України, Адміністрації Державної прикордонної служби України, Міністерства юстиції України від 16.11.2012 № 114/1042/516/1199/936/1687/5. Дата оновлення: 17.04.2019. URL: https://zakon.rada.gov.ua/laws/show/ v0114900-12 (дата звернення 19.04.2019).

9. Оперативно-розшукова діяльність органів внутрішніх справ : Загальна частина : підручник / С. В. Албул, К. І. Бєляков та ін. ; за ред. С. П. Черних, М. П. Водька, О. Ф. Долженкова. Київ : Відділ редакційно-видавничої діяльності МВС України, 2012. 884 с.

10. Galuychek A. The Use of Undercover Forces in Law Enforcement Agencies of the Ukraine in Organized Crime Fighting: The Legal Aspect. Law Enforcement Executive Forum. USA, Illinois, 2005. № 5 (4). P. 59-64.

11. Albul S. V. Philosophic Concepts of the Intelligence Function within the Operative-Investigative Activity of the National Police of Ukraine. European Reforms Bulletin: international scientific peerreviewed journal. Grand Duchy of Luxembourg, 2017. № 1. P. 5-9.

12. Gribov, M. L. The improvement of the institute of secret investigatory operations. Euro-American Scientific Cooperation. Ontario, Canada, 2014. № 2. P. 73-78.

13. Водько Н. П. Формирование политики противодействия уголовным правонарушениям в Украине (оперативно-розыскной аспект) : монография. Одесса : Феникс, 2015. 572 с.

14. Hirschmann Kai. Geheimdienste. Hamburg: Sabine Groenewold Verlag, 2004. $52 \mathrm{~s}$.

15. Цехан Д. М. Інформація як змістовна складова ОРД. Південноукраӥнський правничий часопис. Одеса, 2009. № 2. С. 67-74.

16. Бандурка О. М., Перепелиця М. М., Манжай О. В., Шендрик В. В. Оперативно-розшукова компаративістика : монографія. Харків : Золота міля, 2013. 352 с. 
17. Савченко А. В., Матвійчук В. В., Никифорчук Д. Й. Міжнародний досвід використання агентури правоохоронними органами держав Свропи та США : посібник. / А. В. Савченко, В. В. Матвійчук, Д. Й. Никифорчук / За ред. Я. Ю. Кондратьєва. Київ : НАВС, $2004.60 \mathrm{c}$.

18. Шендрик В. В. Міжнародний досвід використання підрозділів поліції для отримання оперативно-розшукової інформації. Право і Безпека. Київ, 2009. № 1. С. 24-29.

19. Еенбум Е. Ш. Розвідки Північної Америки, Свропи та Японії. Країнознавчий портрет і аналіз : монографія. Вайнгайм : Вид-во. Stoppel, 1995. 212 с.

\section{Information about the author:} Albul S. V.

Ph.D., Associate Professor, Professor at the Department of Operatively-Search Activities, Odesa State University of Internal Affairs 1, Uspenskaya str., Odesa, 65014, Ukraine 